\title{
Methodological proposal for the implementation of bike-share applied to the Brazilian context
}

\author{
Philippe Barbosa Silva \\ University of Brasilia, Brazil \\ Adriana Modesto de Sousa \\ University of Brasilia, Brazil \\ Rodrigo Azevedo Oliveira \\ University of Brasilia, Brazil \\ Juan Pablo Espana Gómez \\ University of Brasilia, Brazil
}

\begin{abstract}
The main objective of this study is to analyze the bicycle rental system in the Federal District "Bike Brasilia". It aims to identify guidelines that supported the application process and consensus, disagreements and guidelines established by the Institute for Policies and Development in Transportation - ITDP and relate those listed by Zhang regarding rented bikes systems. This is an exploratory study based on the strategy of document analysis and its secondary sources: institutional documents, basic design, procurement and other official documents made exclusively for this study. To support the discussion, a systematic literature review of the rules describing specially: sustainability, transport, urban mobility, bicycle rental and environment. The results reveal that while some of the parameters and indicators of efficiency are met on time, the bicycle sharing system of the city of Brasilia, has weaknesses that can lead to inefficiency and impracticality of maintaining and expanding such services. On the other hand, Bike Brasilia partially fulfills the principles enumerated by Zhang and lacks improvement in the steps for the successful operation of the system
\end{abstract}

\section{INTRODUCTION}

Public managers within the urban mobility have sought alternatives to solve problems by congestion deflagrated, space limitations, precariousness of public transport services, high road accidentally and environmental pollution. Among these alternatives appear the Bike Share. Vasconcellos (2008) points out that in that expands the use of bicycles swells the need to create spaces suitable for the use of this modal, reflecting the promotion of behavior change. The offer of an alternative transport service does not necessarily imply the accession by the population, lacking of structural additions and encouragement.

\subsection{Sustainability and Transport}

For Pearce et al. (1989), sustainable development concerns about economic and social system driven by increased power of consumption, improving the quality of life and social well-being. Seabra et al., (2013) report that sustainability in transport consist on attention on accessibility needs for current and future mobility, resulting in a positive impact on economic, social and environmental dimensions. The National Association of Public Transportation of Brazil- ANTP (2005) incorporates the integrality, which is able to cover pollution reduction actions and environmental education, creating new mobility habits, establishing integrated networks and rationalization of transport modes contemplating physical integration, tariff, institutional and operational criteria. Corroborating this integrative perspective, the National Policy for Sustainable Urban Mobility (Brazil, 2004) is 
oriented by the perception that sustainable mobility is the result of the junction of transport and traffic policies, with the objective of increase access by democratic means from prioritization of public transport supply and unmonitored, effective, socially inclusive and environmentally sustainable.

The concern for sustainable mobility refers to the 1980s (UN-HABITAT, 2013), but despite this, emerging and/or developing countries persist in calling for motorized transport (Amorim et al., 2014). These authors believe that to achieve sustainable mobility should be sought modal changes, increasing public transportation and supplying and non-motorized modes of transport. These precepts converge with the Mobility Plan for Cycling in Cities (Brazil, 2007) drawn from four areas: urban development, environmental sustainability, social inclusion and democratization of space.

In this sense, the bicycle can be seen as a strategy for social inclusion, reduction and elimination of pollutants and improving the health of the population. The use of bicycles has been seen as an alternative to the use of motor vehicles, even lacking adequate urban infrastructure with its use and resistance to abandoning the car (Xavier, 2007; Zunino, 2007). In the Brazilian context the advantage of bicycle use supplies an economical lack gaining adherents of other social classes when related to healthy lifestyle habits. This has pushed the government to improve bicycle traffic conditions, even in isolation and in areas of timely coverage. Consort some private companies have invested in the modal tapping the potential of positive visibility through agreements with municipalities, although timidly, cities as Rio de Janeiro, Sao Paulo, Recife, Porto Alegre, Curitiba and Brasília are noteworthy in offering the service (Cadena, Andrade and Brazil, 2014).

\subsection{Bike Share System in the world and in Brazil}

Under the Bike Share it highlights some relevant experience considering his international expressiveness. The Wuhan Public Bikes, introduced in 2009 is considered the world's system overcoming the famous Hangzhou Public Bicycle, also Chinese (Melo, 2013; Qionzqiong, 2013). Its design was instructed to establish connections between stations and other city facilities (Zhang, 2011). The Vélib in Paris (2007) is the largest western system of bike share, highlighting its concern with urban and historical landscape integration (Melo, 2013; Beroud, et al., 2010). Barclays Cycle Here in London, launched in 2010 included the implementation of feasibility study of contribution made in 2008 offering guidelines to the program and actions necessary to maintain being the $2^{\text {nd }}$ largest in Europe. Failed in the aspect of completeness in 2015 was replaced by Santander Cycles.

In the Brazilian context, Bike Rio was implemented in 2008. It sought to present itself as a sustainable solution to mobility over short distances. Almost all stations are installed in the south of the city. The $1^{\text {st }}$ hour of use of the service is free as long as there 15 minutes between trips (Department of Transportation's Federal District, 2013). The Pedal BH (Belo Horizonte) was installed in 2005, anchored in the Incentive Program to Use Bicycle. For its implementation was considered: the implementation of a preliminary bikeway program and the development of a deployment strategy of educational campaigns for the use of bicycles. Preliminary studies revealed that $90 \%$ of the displacements were short, $85 \%$ were motivated by the work and/or study and only $1.73 \%$ of trips aimed at integration with public transport. For the installation of the stations was conducted local research potential (Municipality of Belo Horizonte, 2013). By the other side, Bike Brasilia consists of intelligent stations powered by solar energy and connected with a central of operations. Registered users can 
remove the bike at any station and return it in the same condition. The design that anchors Bike Brasilia aims to introduce and encourage the use of sustainable modal in the light of promoting healthy lifestyle (Department of Transportation's Federal District, 2013).

\section{REFERENCE METHODOLOGICAL DESIGNS}

We proceeded to the analysis of three methods chosen for the suitability to the study, expressiveness and relevance in the subject.

One of the methodologies adopted is the proposed by the Institute for Transportation \& Development Policy (ITDP) in 2013 by The Bike-share Planning Guide, Guide Bicycles Shared Systems Planning in the Portuguese version edited by ITDP Brazil. It is a guiding document and containing indicative for the proper planning of bike-sharing systems. The second choice is the methodology developed by Zhang (2011), which scores in their proposals to a technical-scientific analysis of traffic demand and coverage of bike sharing systems, should consider other factors involved. Finally, also considered is the model proposed by Batista (2010), who developed a model applicable to Brazilian medium-sized cities.

Having regard to the association between parameters, on this study, we chose to list by axle points observed in the implementation process of a bike share system.

\subsection{Viability}

The feasibility study deployment of a bike share system is the starting point of planning. The ITDP (2013) shows some considerations for gauging the feasibility of the project, among the demand, financial feasibility, risk and barriers analyses. Batista (2010) reiterates the need for demand studies users.

Wuhan, Paris and London systems were preceded by feasibility studies (Melo, 2013), as well as in the cities of Brasilia, Rio de Janeiro and Belo Horizonte, and the planning team adopted the parameters considered more relevant for each system. However, Zhang (2011) highlights the importance of analyzing beyond the traffic demand and scope of each system, and the necessity to understand the behavior of the system users; for this, it proposes a characterization of the users, with profiles and allowing the evaluation of the system by users (after implantation), and consequently, system optimization. Another aspect of utmost importance is the manner of operation and financing of the system, establishing in various ways, as a partnership with the private sector.

\subsection{Infrastructure}

The infrastructure of the bike-sharing system is crucial to the success of the venture. Batista (2010) proposes a division of bike traffic zones and analysis of flow between them for the determination of relevant system components, such as location and number of stations, number of bicycles and number of slots per station.

For ITDP (2013), definitions of system components should be based on previous studies and ensure minimum area of system coverage, appropriate density of stations, reasonable number of bicycles for residents, minimum number of bicycle seats, in addition to base the choose the type of bike stations model and mode of operation.

By the other way, Zhang (2011) states that in addition to the mentioned parameters, it is important for system optimization and distribution of stations, to make analysis of 
information as networking, population distribution, distribution of subway stations, distribution of bus stops and land use, facilitated by the use of Geographic Information System tools (GIS). The author also lists parameters for the definition of the cycle network and performance of bike paths.

In the case of Vélib', a special concern was given to the integration of the stations and the urban landscape, ensuring also maximum distance between stations and location of these, in order to avoid obstacles for users. Also in Paris, there were serious problems due to acts of theft and vandalism (Melo, 2013).

In the case of Barclays Cycle Hire, occurred serious problems related to the implementation of the system, for example, in central London the location of the stations were built in a few meters from the stations, not allowing direct integration with the public transportation network (Melo, 2013).

In Wuhan Public Bikes in China, the stations are in locations that satisfied different demands, prioritizing connect the stations with other city facilities (recreational and business areas, subway stations, educational institutions, residences, etc.) (Melo, 2013).

In the case of the analyzed Brazilian cities, were evident the failure in the system scope (small cover area, small number of stations and bicycles, etc.), as well as lack of integration with the public transport network. It is assumed that it does not lead to high utilization and performance of the systems (Department of Transportation's Federal District, 2013; City of Belo Horizonte, 2013; Melo, 2013).

\section{PROPOSAL METHODOLOGY OF BIKE SHARE SYSTEM DEPLOYMENT FOR BRAZILIAN CONTEXT}

Based on the study of methodologies, experiences, considering positive and weaknesses and insertion of relevant parameters analysis on the applicability to the Brazilian reality of bike sharing systems, this work make the proposition of a systems implementation methodology bike-sharing to the Brazilian context.

Before implementation of a bike-sharing system, it is necessary to conduce feasibility studies, this being cast as the first axis of the methodology. At this stage, some information should be considered, particularly:

- Coverage area: first, must define the system's coverage area, determining which areas will compose the system.

- Demand Analysis: known coverage area, one should proceed to the demarcation of traffic zones and determination of existing flows, as well as the movements between the zones; Furthermore, it is important to characterize users through profiles, refers it interesting collection of socioeconomic data, individual habits and beliefs regarding the implementation of the system.

- Environmental and cultural factors: in addition to the technical data reported by all methodologies analyzed for the Brazilian reality, it is crucial to consider environmental factors as climate, topography and land use and occupation. These factors will act in propensity or not use of the system; cultural factors such as the use of bicycle culture and encourage the use of bicycles are important, basically, because 
they reveal the potential adherence and acceptability of the system and can also guide awareness campaigns and dissemination system.

- Financial feasibility analysis: this analysis is essential for the system design with forms of financing to maintaining the system and studying the possibilities for more appropriate partnerships for each situation. Another important aspect is the definition of tariffs depending on the attractiveness to users and consider ways of gratuity to overcome the resistance of citizens to use the system.

- Risk analysis: it is fundamental to analyze the risks and barriers for the present and the future implementation of a bike share system in order to evaluate the necessity of interventions to overcome these obstacles or abortion of system design.

After analyzing the feasibility and option for the implementation of bike sharing system, structural aspects must be defined, including:

- Bike paths/Bike lanes: the cycle network is necessary for safety and smooth flow is ensured for cyclists and should be carried, so in the case of absence, the implementation of bike paths or bike lanes compatibles with the chosen coverage area and in order to minimize traffic conflicts with pedestrians and motor vehicles.

- Bicycles: the system of the vehicle must be adequate to the characteristics of the infrastructure and operational issues, which guide the definition of the type and model, in addition to safety equipment for use, locking system and tracking bike.

- Stations: similarly, based on information collected, it is necessary to adopt the type and model of the stations, opting for automatic and modular stations (removable) or permanent; the proper choice of the locking system is also essential, given the possibility of theft and vandalism actions. It must also perform the system design and can be divided into two areas as spatial features and accessibility and integration.

- Spatial Features: setting the number of stations should consider the population served, system coverage area and distance between stations (this can be defined as the distance comfortable for user access to the system). Another aspect of the location of stations should give mainly for integration with these areas and the transport network, analyzing the demand, minimizing conflicts with urban equipment and considerations regarding the land use and occupation. It is also necessary to set the number of spaces per station; allowing users to achieve satisfactorily leave the bike at the station of his choice.

- Accessibility and integration: the stations should prevail accessibility for users, integration with other stations, integration with public transportation network, integration with commercial areas, residential, recreational and leisure activities and even tariff integration with other modes carriage.

- Operation: information technology systems, tariffs, payment mechanisms and marketing are relevant parameters for the system operation.

\section{CONCLUSIONS}

In the proposed methodological procedure, were considered good practices -and weaknesses- observed on the procedures and analyzed experiences, incorporating also relevant parameters for the Brazilian reality.

It is to highlight the need for consideration of environmental and cultural factors in the target 
city's implementation of a bike-sharing system, since climate issues, relief, city size and land use are crucial to use the system, as well as the use of bicycles culture and incentive policies to this kind of sustainable transport.

In Brazil, it is also important to consider issues related to bike paths/bike lanes, as few Brazilian cities have an incipient bicycle network, constituting therefore the implementation of roads as a key factor in the system design process. In this scenario were cycle network already exist, it may prejudge the system settings, such as bicycles, coverage area and stations.

The Brazilian reality also demand special attention to bicycle tracking, locking and security stations system, being due to study the adequacy of systems and safety devices on each system.

Another important aspect to be considered, considering the deep-rooted culture of car use and resistance to transport non-motorized modes is the low tariffs and payment, may be the initial attraction to show the benefits of this kind of systems. Also in this occasion, it is quite important that systemic actions are taken and well-structured marketing.

Finally, it is considered that the proposed methodology provides indications for planning the implementation of bike sharing systems in Brazilian cities, signaling the main parameters that should be investigated, without which one can compromise the success and viability of a system.

\section{ACKNOWLEDGEMENTS}

We thank to the Research Support Foundation of the Federal District (FAP-DF) for financial support.

\section{REFERENCES}

AMORIM, L. C.; G. M. OliveIRA, A. N. R. Silva (2014). UMA VISÃO DE MOBILIDADE URBANA SUSTENTÁVEL SEGUNDO O DISCURSO DE PESQUISADORES E TÉCNICOS/GESTORES. XXVIII Congresso de Pesquisa e Ensino em Transportes (ANPET), 24-28 Novembro 2014. Curitiba, Brasil.

ANTP (2005). Transporte e Mobilidade Sustentável. Tese da Comissão de Meio Ambiente da ANTP. Revista dos Transportes Públicos - ANTP, v. 27/28, n. 107/108, p. 81-92.

BATISTA, E. A. D. (2010). Bicycle Sharing in Developing Countries: A proposal towards sustainable transportation in Brazilian median cities. 112p. Dissertação (Mestrado em Industrial Ecology). Royal Institute of Technology, Stockholm.

CADENA, R. P.; ANDRADE, M. O.; BRASILEIRO A. (2014). A NECESSIDADE DA REGULAÇÃO DO ALUGUEL DE BICICLETAS COMO SERVIÇO PÚBLICO COMPLEMENTAR AO TRANSPORTE URBANO. XXVIII Congresso de Pesquisa $e$ Ensino em Transportes (ANPET), 24-28 Novembro 2014. Curitiba, Brasil.

GIL, A. C. (1999). Métodos e Técnicas de pesquisa social. $5^{\mathrm{a}}$ ed., Editora Atlas, São Paulo.

ITDP. GUIA DE PLANEJAMENTO DE SISTEMAS DE BICICLETAS COMPARTILHADAS. Instituto de Políticas de Transporte e Desenvolvimento, Rio de 
Janeiro, 2013.

MELO, M. F. S. (2013). SISTEMA DE BICICLETAS PÚBLICAS: UMA ALTERNATIVA PARA PROMOÇÃO DA MOBILIDADE URBANA SUSTENTÁVEL NO MUNICÍPIO DE RECIFE. 215p. Dissertação (Mestrado em Engenharia Civil). Universidade Federal de Pernambuco, UFPE, Recife.

MINISTÉRIO DAS CIDADES. Cadernos MCidades. Vol. 6: Política Nacional de Mobilidade Urbana Sustentável. Brasília: Ministério das Cidades. 2004.

MINISTÉRIO DAS CIDADES. Programa Brasileiro de Mobilidade por Bicicleta BICICLETA BRASIL. Caderno de referência para elaboração de Plano de Mobilidade por bicicletas nas Cidades. Brasília: Secretaria Nacional de Transporte e Mobilidade Urbana, 2007.

PDTU - Relatório Técnico $\mathrm{n}^{\circ}$ 7: Cenário de desenvolvimento. PLANO DIRETOR DE TRANSPORTE URBANO E MOBILIDADE DO DISTRITO FEDERAL E ENTORNO, Brasília, 2010.

PEARCE, D.; MARKANDYA, A.; BARBIER E. B. (1989). Blueprint for a Green Economy. Earthscan Publications Ltd, London.

POUPART J, et al. (2012). A pesquisa qualitativa: enfoques epistemológicos $e$ metodológicos. $3^{\mathrm{a}}$ ed. Editora Vozes, Petrópolis, Brasil.

PREFEITURA MUNICIPAL DE BELO HORIZONTE. BHTrans. Termo de Referência, 2013.

Seabra, L. O.; Taco, P. W. G.; Dominguez, E. M. (2013). Sustentabilidade em transportes: do conceito às políticas públicas de mobilidade urbana. Revista dos Transportes Públicos ANTP, Planejamento e Gestão Urbana, pp. 103-124.

SECRETARIA DE TRANSPORTES DO DISTRITO FEDERAL. Estudos de Transporte para Exploração do Sistema de Bicicletas de Aluguel no DF - Relatório de demanda, rotas e estudos socioeconômicos, 2013.

UN-Habitat. Planning and Design for Sustainable Urban Mobility: Policy Directions. United Nations Human Settlements Programme, Nairobi; Earthscan from Routledge, Abingdon [etc.], 2013.

VASCONCELLOS, E. A. (2008). Transportes e Meio Ambiente: conceitos e informações para análise de impactos. Editora AnnaBlume, São Paulo.

XAVIER, G. N. A. (2007). O cicloativismo no Brasil e a produção da lei de política nacional de mobilidade urbana. Revista Eletrônica dos Pós-Graduandos em sociologia Política da UFSC, 2 (2), pp. 16-21.

ZUNINO, L. R. (2007) Parque vivencial como ferramenta educacional de incentivo à mobilidade sustentável. 202p. Tese (Doutorado em Engenharia de Transporte). Universidade Federal do Rio de Janeiro, UFRJ/COPPE, Rio de Janeiro. 